\title{
Vanadium pentoxide induces the secretion of CXCL9 and CXCL10 chemokines in thyroid cells
}

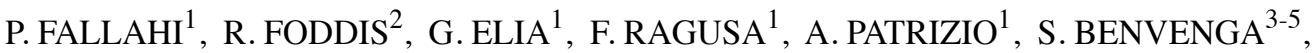 \\ A. CRISTAUDO ${ }^{2}$, A. ANTONELLI ${ }^{1}$ and S.M. FERRARI ${ }^{1}$
}

\begin{abstract}
Departments of ${ }^{1}$ Clinical and Experimental Medicine and ${ }^{2}$ Translational Research and New Technologies in Medicine and Surgery, University of Pisa, I-56126 Pisa; ${ }^{3}$ Department of Clinical and Experimental Medicine, Section of Endocrinology and ${ }^{4}$ Master Program on Childhood, Adolescent and Women's Endocrine Health, University of Messina, I-98125 Messina; ${ }^{5}$ Interdepartmental Program on Molecular and Clinical Endocrinology, and Women's Endocrine Health, Azienda Ospedaliera Universitaria Policlinico 'G. Martino', I-98125 Messina, Italy
\end{abstract}

Received November 1, 2017; Accepted March 1, 2018

DOI: 10.3892/or.2018.6307

\begin{abstract}
Vanadium is a grey metal, existing in different states of oxidation, whose most common form in commercial products is vanadium pentoxide $\left(\mathrm{V}_{2} \mathrm{O}_{5}\right)$. All vanadium compounds have been considered toxic. A carcinogenic role of vanadium on the thyroid has recently been proposed. However no in vivo or in vitro studies have evaluated thyroid disruption in humans and/or animals after exposure to vanadium. In the present study we evaluate the effect of $\mathrm{V}_{2} \mathrm{O}_{5}$ on proliferation, and chemokine secretion in normal thyrocytes. Our study demonstrated that $\mathrm{V}_{2} \mathrm{O}_{5}$ has no effect on thyroid follicular cell viability or proliferation, but it is able to induce the secretion of T-helper (Th)1 chemokines into the thyroid, synergistically increasing the effect of important Th1 cytokines such as interferon (IFN) $\gamma$ and tumor necrosis factor (TNF) $\alpha$. Through this process, $\mathrm{V}_{2} \mathrm{O}_{5}$ promotes the induction and perpetuation of an inflammatory reaction in the thyroid. Further studies are necessary to evaluate thyroid function, and nodules, in subjects occupationally exposed, or living in polluted areas.
\end{abstract}

\section{Introduction}

Vanadium is a grey metal that exists in a number of different states of oxidation: $-1,0,+2,+3,+4$ and +5 . The most common form in commercial products is vanadium pentoxide $\left(\mathrm{V}_{2} \mathrm{O}_{5}\right)$. All vanadium compounds have been considered toxic. The maximum amount of human $\mathrm{V}_{2} \mathrm{O}_{5}$ exposure has been established by the Occupational Safety and Health Administration of the US Department of Labor as $0.05 \mathrm{mg} / \mathrm{m}^{3}$ for dust and

Correspondence to: Professor Alessandro Antonelli, Department of Clinical and Experimental Medicine, University of Pisa, School of Medicine, Via Savi 10, I-56126 Pisa, Italy

E-mail: alessandro.antonelli@med.unipi.it

Key words: vanadium, CXCL10, CXCL9, chemokines, thyroid cells, environmental exposure, occupational exposure
$0.1 \mathrm{mg} / \mathrm{m}^{3}$ for fumes, in workplace air for an $8 \mathrm{~h}$ workday $/ 40 \mathrm{~h}$ work week (1). Exposure to a $35 \mathrm{mg} / \mathrm{m}^{3}$ dose of vanadium is considered life-threatening and could provoke serious and perpetual health issues including death, as determined by The National Institute for Occupational Safety and Health (1).

The respiratory system is the most vulnerable system to the toxic effect of vanadium whereas there is inconsequential action on the gastrointestinal system due to the minimal gut absorption rate of the substance (2-4). Unfortunately, we lack satisfactory data to determine the reference range of a subchronic or chronic inhaled dose. The effects resulting from an oral or inhaled vanadium exposure on serum parameters $(5,6)$, the liver (7), nervous system (8) and development of other tissues have been described in rat models (9).

Recently, the increase in the incidence of thyroid cancer in areas of volcanic activity suggest a carcinogenic effect of volcanic pollution. In the Mount Etna volcanic area, the incidence of thyroid cancer was higher than that in control areas (18.5 and 9.6/105 inhabitants, respectively). In volcanic areas, various trace elements are increased (with respect to control areas) in both lichens and drinking water, indicating atmospheric and water pollution. The amounts of trace elements are significantly increased, among them vanadium which was increased 8 times, and its possible carcinogenic role on the thyroid has been hypothesized $(10,11)$.

However, no in vivo or in vitro studies have evaluated thyroid/endocrine disruption in humans and/or animals after exposure to vanadium. In the present study, we evaluated the effect of $\mathrm{V}_{2} \mathrm{O}_{5}$ on the proliferation and chemokine secretion of normal thyrocytes.

\section{Materials and methods}

Thyroid follicular cells (TFCs). We collected 10 specimens of thyroid tissue from 10 euthyroid patients (mean age, 41 years, range 24-61; 5 females, 5 males) (8 undergoing parathyroidectomy, 2 laryngeal intervention). We obtained informed consent from all participants, and the local ethics committee of the University of Pisa provided approval for the study. Thyrocytes were prepared as previously described (12-14). 
The digestion of tissue samples was carried out by collagenase (Roche Diagnostics GmbH, Mannheim, Germany; $1 \mathrm{mg} / \mathrm{ml}$ ) with RPMI-1640 (Whittaker Bioproducts, Inc., Walkersville, MD, USA) for $1 \mathrm{~h}$ at $37^{\circ} \mathrm{C}$. The semi-digested follicles were removed and sedimented for $2 \mathrm{~min}$; they were then washed and cultured with RPMI-1640 medium in the presence of fetal bovine serum (FBS) 10\% (Seromed Biochrome, Berlin, Germany), $50 \mathrm{mg} / \mathrm{ml}$ penicillin/streptomycin, $2 \mathrm{mM}$ glutamine, with $5 \% \mathrm{CO}_{2}$ at $37^{\circ} \mathrm{C}$.

Cell viability and proliferation assay. Cell viability and proliferation were evaluated using the WST-1 (Roche Diagnostics, Almere, The Netherlands) assay (which uses 3-[4,5-dimethylthiazol-2-yl]-2,5-diphenyltetrazolium bromide, in the MTT assay) (15-17). TFCs were seeded at a density of 35,000 cells $/ \mathrm{ml}$ (in a final volume of $100 \mu \mathrm{l}$ ) in each well of 96-well plates. To determine how $\mathrm{V}_{2} \mathrm{O}_{5}$ affects TFC proliferation, the cells were treated $(24 \mathrm{~h})$ with increasing concentrations of $\mathrm{V}_{2} \mathrm{O}_{5}(1,10$ and $100 \mathrm{nM}$ ). For each cell preparation, the experiments were performed in triplicate. Cells were plated and treated for $24 \mathrm{~h}$ with $\mathrm{V}_{2} \mathrm{O}_{5}$ or with its vehicle alone.

Proliferation assay: Cell counting. Cell number counting was also used to evaluate the proliferation of TFCs as previously described (15-17).

Chemokine secretion assays. To successfully perform the chemokine (C-X-C motif) ligand (CXCL)9, or CXCL10 secretion assays, 30,000 cells/ml were seeded (in 96-well plates) in a final volume of $100 \mu \mathrm{l} / \mathrm{well}$, in growth medium, which was then removed (after $24 \mathrm{~h}$ ). Cells were then washed with phosphate-buffered saline (PBS) and incubated (for $24 \mathrm{~h})$ in serum and phenol red-free medium with interferon (IFN) $\gamma(500,1,000,5,000$ and 10,000 IU/ml; R\&D Systems, Minneapolis, MN, USA) and tumor necrosis factor (TNF) $\alpha(10 \mathrm{ng} / \mathrm{ml})$ (R\&D Systems), in combination (13) or alone. The TNF $\alpha$ concentration was chosen to obtain the highest secretion in preliminary experiments. The supernatant was then obtained (after $24 \mathrm{~h}$ ), and kept frozen at $-20^{\circ} \mathrm{C}$ (until chemokine assay).

To understand how $\mathrm{V}_{2} \mathrm{O}_{5}$ affects the chemokine secretion induced by IFN $\gamma$, the cells were treated (for $24 \mathrm{~h}$ ) with increasing concentrations of $\mathrm{V}_{2} \mathrm{O}_{5}(1,10$ and $100 \mathrm{nM})$, in the presence/absence of IFN $\gamma(1,000 \mathrm{IU} / \mathrm{ml})$ and/or TNF $\alpha$ (10 ng/ml). CXCL9 and CXCL10 in the supernatants were measured by ELISA. The experiments were conducted 3 times with each different cell preparation.

ELISA for CXCL9 and CXCL10. CXCL9 or CXCL10 was assessed in the supernatants from cell cultures by commercially prepared kits (R\&D Systems). The minimum (mean) detectable doses were 1.5 or $1.2 \mathrm{pg} / \mathrm{ml}$, for CXCL9, or CXCL10 (respectively). The intra- and inter-assay coefficients of variation were for 3.5 and $6.4 \%$, respectively, for CXCL9, while these coefficients for CXCL10 were 4.5 and $7.3 \%$, respectively. Quality control pools of normal, low and high concentrations were also included in each assay.

Data analysis. For normally distributed variables, the values are expressed in the text as mean $( \pm$ SD), or mean $( \pm$ SEM) in

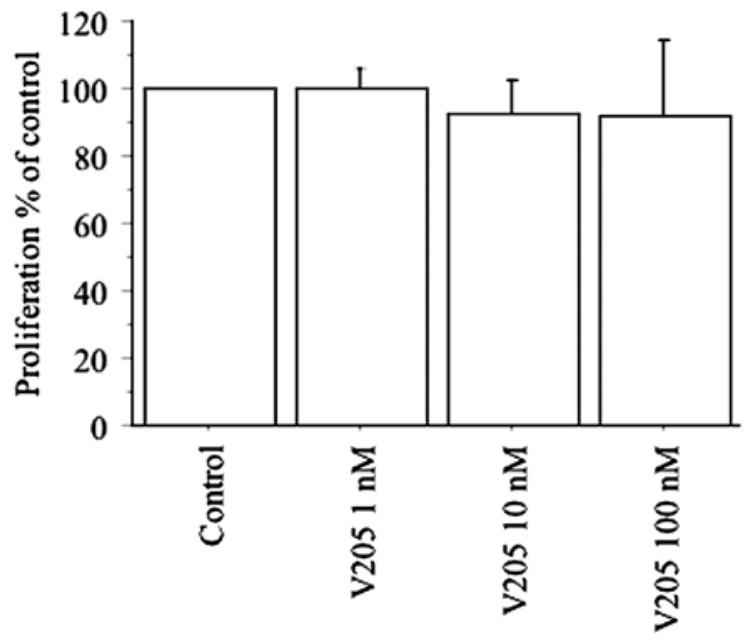

Figure 1. Cell viability and proliferation assay WST-1 showed that $\mathrm{V}_{2} \mathrm{O}_{5}$ (V2O5; 1, 10 and $100 \mathrm{nM}$ ) did not alter the viability or proliferation of TFCs [mean group values are compared by using one-way analysis of variance (ANOVA); the Bonferroni-Dunn test was used for post hoc comparison; $\mathrm{P}>0.05$, for all comparisons]

figures, otherwise as median [and interquartile range]. Mean group values were compared by using one-way analysis of variance (ANOVA) for variables normally distributed, or with the Kruskal-Wallis test, or Mann-Whitney U test. Proportions were compared by the Chi-square test. The Bonferroni-Dunn test was used for post hoc comparison of normally distributed variables.

\section{Results}

Cell proliferation. Cell viability and proliferation assay WST-1 demonstrated that $\mathrm{V}_{2} \mathrm{O}_{5}(1,10$ and $100 \mathrm{nM})$ did not alter the viability or proliferation of the TFCs (Fig. 1). These results were confirmed by cell counting (data not shown).

CXCL9. CXCL9 levels were not detectable in supernatants gathered from primary thyrocyte samples, whereas the CXCL9 concentration was increased after dose-dependent induction of IFN $\gamma(0,61 \pm 27,136 \pm 34,196 \pm 41$ and $262 \pm 67 \mathrm{pg} / \mathrm{ml}$; with IFN $\gamma$ 0, 500, 1,000, 5,000 and 10,000 IU/ml, respectively; $\mathrm{P}<0.001$ by ANOVA). TNF $\alpha$ alone was not able to promote any impact on CXCL9 (remaining undetectable), while the synergy of IFN $\gamma$ plus TNF $\alpha$ elicited a significant influence on CXCL9 release (CXCL9, 8976 \pm 1456 vs. $142 \pm 34 \mathrm{pg} / \mathrm{ml}$ with IFN $\gamma$ alone, $\mathrm{P}<0.0001$ by ANOVA).

Following the treatment of thyrocytes with $\mathrm{V}_{2} \mathrm{O}_{5}(1,10$ and $100 \mathrm{nM}$ ), CXCL9 secretion was dose-dependently stimulated (ANOVA, $\mathrm{P}<0.0001$ ) (Fig. 2A). Following the treatment of thyrocytes with $\mathrm{V}_{2} \mathrm{O}_{5}(1,10$ and $100 \mathrm{nM})$, together with TNF $\alpha$, CXCL9 secretion was not significantly altered with respect to $\mathrm{V}_{2} \mathrm{O}_{5}$ alone (data not shown).

Following the treatment of thyrocytes with $\mathrm{V}_{2} \mathrm{O}_{5}(100 \mathrm{nM})$, together with IFN $\gamma$, CXCL9 release was synergistically increased (ANOVA, $\mathrm{P}<0.0001$ ) (Fig. 3A).

Following the treatment of thyrocytes with $\mathrm{V}_{2} \mathrm{O}_{5}(100 \mathrm{nM})$, together with IFN $\gamma$ and TNF $\alpha$, CXCL9 secretion was synergistically increased (ANOVA, $\mathrm{P}<0.0001$ ) (Fig. 4A). 

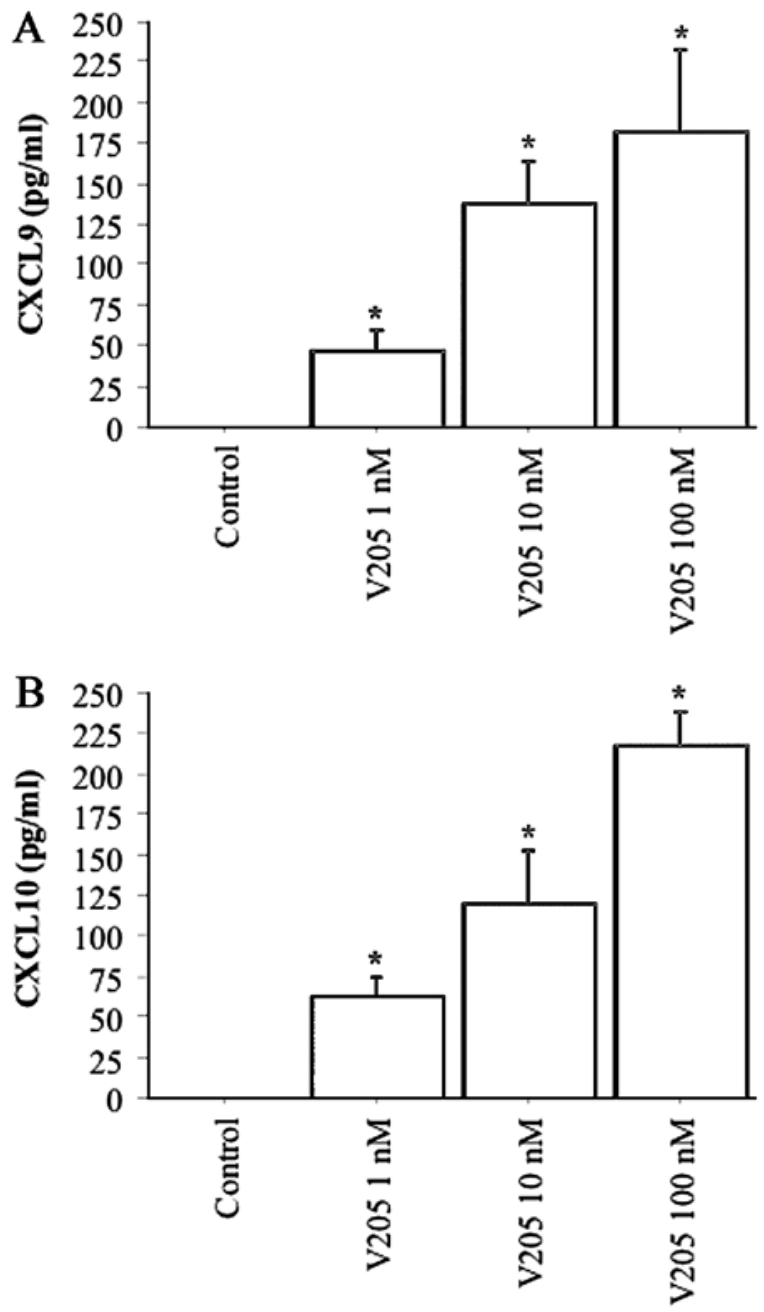

Figure 2. (A) Following treatment of thyrocytes with $\mathrm{V}_{2} \mathrm{O}_{5}$ (V2O5; 1,10 and $100 \mathrm{nM}$ ), CXCL9 secretion was dose-dependently stimulated $(\mathrm{P}<0.0001$, by ANOVA). (B) Following treatment of thyrocytes with $\mathrm{V}_{2} \mathrm{O}_{5}(\mathrm{~V} 2 \mathrm{O} 5 ; 1,10$ and $100 \mathrm{nM}$ ), CXCL10 secretion was dose-dependently stimulated ( $\mathrm{P}<0.0001$, by ANOVA) (Bonferroni-Dunn test was used for post hoc comparison; " $\mathrm{P}<0.05$ ).

CXCL10. CXCL10 was not detectable in the supernatants from primary thyrocyte cultures in basal condition. IFN $\gamma$ induced CXCL10 secretion dose-dependently $(0,45 \pm 22,111 \pm 35$, $213 \pm 27,254 \pm 64 \mathrm{pg} / \mathrm{ml}$, with IFN $\gamma 0,500,1,000,5,000$ and $10,000 \mathrm{IU} / \mathrm{ml}$; respectively; $\mathrm{P}<0.001$ by ANOVA). TNF $\alpha$ only was not able in this case to carry out any impact on CXCL10, while the synergy of IFN $\gamma$ plus TNF $\alpha$ elicited a significant influence on CXCL10 secretion $(2,011 \pm 154$ vs. $108 \pm 26 \mathrm{pg} / \mathrm{ml}$ with IFN $\gamma$ alone; $\mathrm{P}<0.0001$, by ANOVA).

Following treatment of thyrocytes with $\mathrm{V}_{2} \mathrm{O}_{5}(1,10$ and $100 \mathrm{nM}$ ) CXCL10 secretion was stimulated dose-dependently ( $\mathrm{P}<0.0001$ by ANOVA) (Fig. 2B). Following treatment of thyrocytes with $\mathrm{V}_{2} \mathrm{O}_{5}(1,10$ and $100 \mathrm{nM})$, together with $\mathrm{TNF} \alpha$, CXCL10 secretion was not significantly changed with respect to $\mathrm{V}_{2} \mathrm{O}_{5}$ alone (data not shown).

Following treatment of thyrocytes with $\mathrm{V}_{2} \mathrm{O}_{5}(100 \mathrm{nM})$, together with IFN $\gamma$, CXCL10 release was synergistically increased $(\mathrm{P}<0.0001$ by ANOVA) (Fig. 3B).

Following treatment of thyrocytes with $\mathrm{V}_{2} \mathrm{O}_{5}(100 \mathrm{nM})$, together with IFN $\gamma$ plus TNF $\alpha$, CXCL10 secretion was synergistically increased ( $\mathrm{P}<0.0001$ by ANOVA) (Fig. 4B).
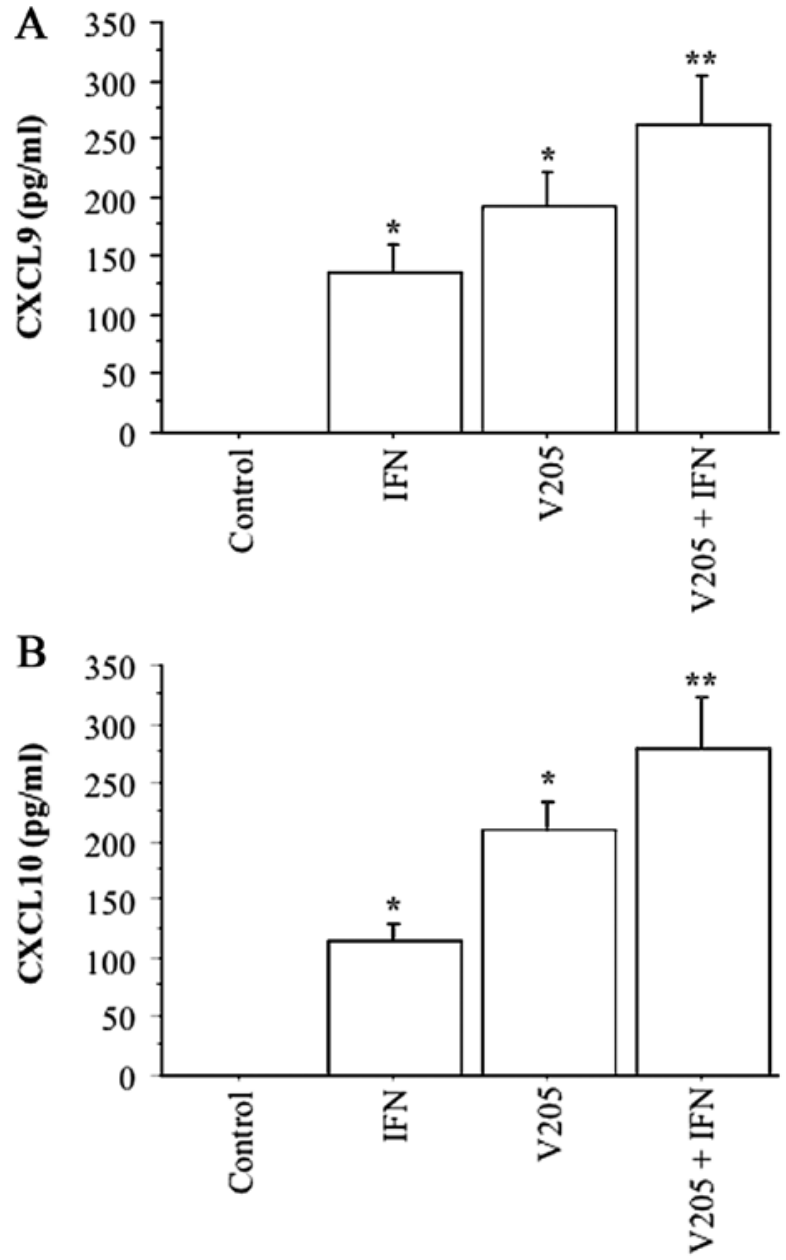

Figure 3. (A) Following treatment of thyrocytes with $\mathrm{V}_{2} \mathrm{O}_{5}$ (V2O5; $100 \mathrm{nM})+\operatorname{IFN} \gamma($ IFN), CXCL9 release was synergistically increased ( $\mathrm{P}<0.0001$, by ANOVA). (B) Following treatment of thyrocytes with $\mathrm{V}_{2} \mathrm{O}_{5}(\mathrm{~V} 2 \mathrm{O} 5 ; 100 \mathrm{nM})+\mathrm{IFN} \gamma($ IFN), CXCL10 release was synergistically increased $(\mathrm{P}<0.0001$, by ANOVA) (Bonferroni-Dunn test was used for post hoc comparison; ${ }^{*} \mathrm{P}<0.05$ vs. control; ${ }^{* *} \mathrm{P}<0.05$ vs. IFN or $\mathrm{V}_{2} \mathrm{O}_{5}$ ).

\section{Discussion}

The results of the present study demonstrated that $\mathrm{V}_{2} \mathrm{O}_{5}$ can promote IFN $\gamma$-dependent chemokine secretion by TFCs, without altering the viability and proliferation of the cells. Moreover, as expected (14), our study confirmed that IFN $\gamma$ and TNF $\alpha$ stimulated the secretion of C-X-C chemokines, CXCL9 and CXCL10, evaluated by ELISA, which is an accepted and commonly published method to dose chemokine levels in supernatants. Notably, $\mathrm{V}_{2} \mathrm{O}_{5}$ was able to synergize with IFN $\gamma$ and $\mathrm{TNF} \alpha$, further increasing chemokine secretion. These results, on the whole, are in agreement with the view that $\mathrm{V}_{2} \mathrm{O}_{5}$ is able to induce and perpetuate an inflammatory disorder in the thyroid evolving from a predominant T-helper (Th)1 immune response (15).

In fact, IFN $\gamma$-inducible $\mathrm{C}-\mathrm{X}$-C chemokines can be secreted by several types of mammalian cells, such as fibroblasts, thyrocytes, islet cells, colon epithelial cells, endothelial cells, and others (12-19). However, in basal condition such cell types do not produce these chemokines, that are secreted after the stimulation with IFN $\gamma$ (alone or in combination with TNF $\alpha$ ), a cytokine that is produced by Th1-activated lymphocytes in 

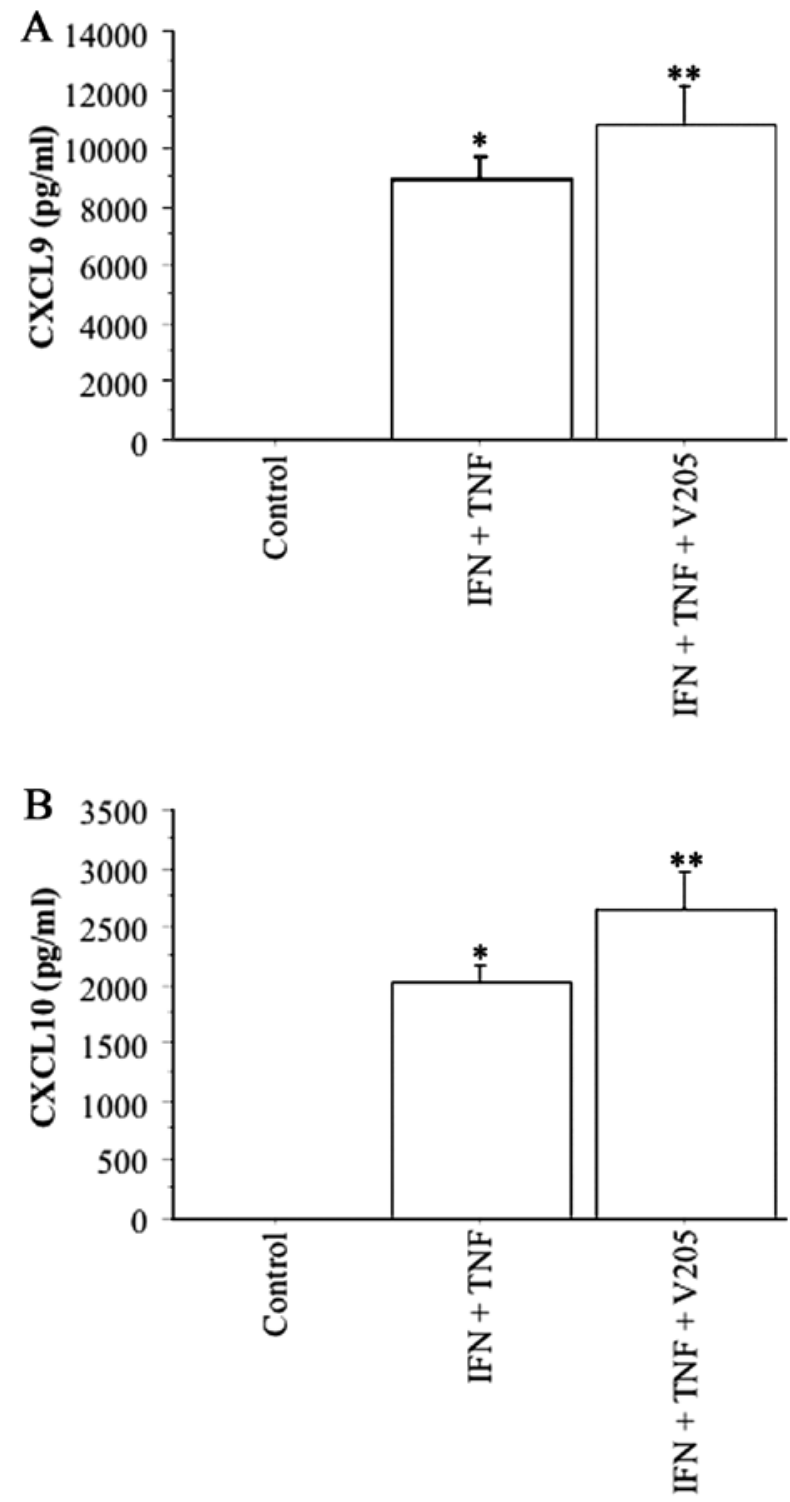

Figure 4. (A) Following treatment of thyrocytes with $\mathrm{V}_{2} \mathrm{O}_{5}(\mathrm{~V} 2 \mathrm{O} 5 ; 100$ $\mathrm{nM})+\mathrm{IFN} \gamma(\mathrm{IFN})+\mathrm{TNF} \alpha$ (TNF), CXCL9 secretion was synergistically increased $(\mathrm{P}<0.0001$, by ANOVA). (B) Following treatment of thyrocytes with $\mathrm{V}_{2} \mathrm{O}_{5}(\mathrm{~V} 2 \mathrm{O} 5 ; 100 \mathrm{nM})+\mathrm{IFN} \gamma(\mathrm{IFN})+\mathrm{TNF} \alpha(\mathrm{TNF}), \mathrm{CXCL} 10$ secretion was synergistically increased $(\mathrm{P}<0.0001$, by ANOVA) (Bonferroni-Dunn test was used for post hoc comparison; ${ }^{*} \mathrm{P}<0.05$ vs. control; ${ }^{* *} \mathrm{P}<0.05$ vs. IFN+TNF).

several autoimmune diseases, for example in the thyroid in Graves' disease, or in autoimmune thyroiditis. This process has been hypothesized to be involved in the initiation and/or the perpetuation in several autoimmune disorders (12-21), and it can be applied also to the thyroid.

Our results agree with those of other researches in different cell types. $\mathrm{V}_{2} \mathrm{O}_{5}$ exposure is a cause of occupational bronchitis, and a study evaluated gene expression profiles in human lung fibroblasts (in cultures) after exposure in vitro to $\mathrm{V}_{2} \mathrm{O}_{5}$ in order to identify genes that may play a role in the bronchial inflammation, repair and fibrosis in the pathogenesis of bronchitis. Approximately 12 genes were overexpressed following exposure to $\mathrm{V}_{2} \mathrm{O}_{5}$, including chemokines (CXCL9, CXCL10 and interleukin-8) (22). In a second study, it was shown that fibroblasts respond to vanadium oxidative stress by producing
IFN $\beta$ and activating STAT-1, that led to increased CXCL10 levels (23), playing a role in the innate immune response.

Importantly, vanadium was able to increase chemokine secretion in a dose range, from 1 to $100 \mathrm{nM}$. It was observed that normal blood levels of vanadium range from 0.45 to $18.4 \mathrm{nM}$, and that $100 \mathrm{nM}$ is a dose that may mimic an abnormally high exposure (24).

The mechanisms by which $\mathrm{V}_{2} \mathrm{O}_{5}$ induces lung cancer have been investigated in mice in numerous studies. Experts agree that in vivo and in vitro research suggests that cancers are induced by secondary mechanisms (probably not genotoxic effects) (25).

Thus, we hypothesized that, also for the thyroid, the induction and perpetuation of an inflammatory reaction into this gland, and the variety of involved candidate genes could predispose to the appearance of thyroid cancer (as recently demonstrated for the association of papillary thyroid cancer and autoimmune thyroiditis), and could be at the basis of $\mathrm{V}_{2} \mathrm{O}_{5}$-induced effects after occupational and environmental exposure.

In conclusion, the present study showed that $\mathrm{V}_{2} \mathrm{O}_{5}$ is able to induce the secretion of Th1 chemokines into the thyroid, synergistically increasing the effect of important Th1 cytokines such as IFN $\gamma$ and TNF $\alpha$, leading to the induction and perpetuation of an inflammatory reaction in the thyroid. Further studies are necessary to investigate the mechanism of action by which chemokines are secreted, and to evaluate thyroid function, and nodules, in subjects occupationally exposed, or living in polluted areas.

\section{Acknowledgements}

Not applicable.

\section{Funding}

No funding was received.

\section{Availability of data and materials}

All data generated or analyzed during this study are included in this published article.

\section{Authors' contributions}

PF, RF, AC, AA and SMF made substantial contributions to conception and design, and to acquisition of data; PF, RF, GE, FR, AP, SB, AC, AA and SMF analysed the data; PF, AA and SMF have been involved in drafting the manuscript; AA revised it critically for important intellectual content. All authors read and approved the manuscript and agree to be accountable for all aspects of the research in ensuring that the accuracy or integrity of any part of the work are appropriately investigated and resolved.

\section{Ethics approval and consent to participate}

Informed consent from all participants was obtained, and the local ethics committee of the University of Pisa provided approval for the study. 


\section{Consent for publication}

Not applicable.

\section{Competing interests}

The authors declare that they have no competing interests.

\section{References}

1. 'Occupational Safety and Health Guidelines for Vanadium Pentoxide'.Occupational Safety andHealth Administration.https:// www.osha.gov/SLTC/healthguidelines/vanadiumpentoxidedust/ recognition. html, Retrieved 29 January 2009.

2. Sax NI: Dangerous Properties of Industrial Materials. 6th edition. Van Nostrand Reinhold Company, New York, pp2717-2720, 1984

3. Ress NB, Chou BJ, Renne RA, Dill JA, Miller RA, Roycroft JH, Hailey JR, Haseman JK and Bucher JR: Carcinogenicity of inhaled vanadium pentoxide in $\mathrm{F} 344 / \mathrm{N}$ rats and $\mathrm{B} 6 \mathrm{C} 3 \mathrm{~F} 1$ mice. Toxicol Sci 74: 287-296, 2003.

4. Wörle-Knirsch JM, Kern K, Schleh C, Adelhelm C, Feldmann C and Krug HF: Nanoparticulate vanadium oxide potentiated vanadium toxicity in human lung cells. Environ Sci Technol 41: 331-336, 2007.

5. Scibior A, Zaporowska H and Ostrowski J: Selected haematological and biochemical parameters of blood in rats after subchronic administration of vanadium and/or magnesium in drinking water. Arch Environ Contam Toxicol 51: 287-295, 2006

6. González-Villalva A,FortoulTI,Avila-CostaMR,Piñón-ZarateG, Rodriguez-Laraa V, Martínez-Levy G, Rojas-Lemus M, BizarroNevarez P,Díaz-Bech P, Mussali-Galante P, et al: Thrombocytosis induced in mice after subacute and subchronic V2O5 inhalation. Toxicol Ind Health 22: 113-116, 2006.

7. Kobayashi K, Himeno S, Satoh M, Kuroda J, Shibata N, Seko Y and Hasegawa T: Pentavalent vanadium induces hepatic metallothionein through interleukin-6-dependent and -independent mechanisms. Toxicology 228: 162-170, 2006.

8. Soazo M and Garcia GB: Vanadium exposure through lactation produces behavioral alterations and CNS myelin deficit in neonatal rats. Neurotoxicol Teratol 29: 503-510, 2007.

9. Barceloux DG and Barceloux D: Vanadium. J Toxicol Clin Toxicol 37: 265-278, 1999.

10. Malandrino P, Russo M, Ronchi A, Minoia C, Cataldo D, Regalbuto C, Giordano C, Attard M, Squatrito S, Trimarchi F, et al: Increased thyroid cancer incidence in a basaltic volcanic area is associated with non-anthropogenic pollution and biocontamination. Endocrine 53: 471-479, 2016.

11. Ferrari SM,Fallahi P,Antonelli A and Benvenga S: Environmental issues in thyroid diseases. Front Endocrinol 8: 50, 2017.

12. García-López MA, Sancho D, Sánchez-Madrid F and Marazuela M: Thyrocytes from autoimmune thyroid disorders produce the chemokines IP-10 and Mig and attract CXCR3+ lymphocytes. J Clin Endocrinol Metab 86: 5008-5016, 2001.
13. Antonelli A, Ferri C, Fallahi P, Ferrari SM, Frascerra S, Sebastiani M, Franzoni F, Galetta F and Ferrannini E: High values of CXCL10 serum levels in patients with hepatitis C associated mixed cryoglobulinemia in presence or absence of autoimmune thyroiditis. Cytokine 42: 137-143, 2008.

14. Antonelli A, Ferrari SM, Fallahi P, Frascerra S, Santini E, Franceschini SS and Ferrannini E: Monokine induced by interferon gamma (IFNgamma) (CXCL9) and IFNgamma inducible T-cell alpha-chemoattractant (CXCL11) involvement in Graves' disease and ophthalmopathy: Modulation by peroxisome proliferator-activated receptor-gamma agonists. J Clin Endocrinol Metab 94: 1803-1809, 2009.

15. Antonelli A, Rotondi M, Fallahi P, Romagnani P, Ferrari SM, Buonamano A, Ferrannini E and Serio M: High levels of circulating CXC chemokine ligand 10 are associated with chronic autoimmune thyroiditis and hypothyroidism. J Clin Endocrinol Metab 89: 5496-5499, 2004.

16. Antonelli A, Ferrari SM, Frascerra S, Pupilli C, Mancusi C, Metelli MR, Orlando C, Ferrannini E and Fallahi P: CXCL9 and CXCL11 chemokines modulation by peroxisome proliferator-activated receptor-alpha agonists secretion in Graves' and normal thyrocytes. J Clin Endocrinol Metab 95: E413-E420, 2010.

17. Kemp EH, Metcalfe RA, Smith KA, Woodroofe MN, Watson PF and Weetman AP: Detection and localization of chemokine gene expression in autoimmune thyroid disease. Clin Endocrinol 59: 207-213, 2003.

18. Antonelli A, Ferrari SM, Corrado A, Ferrannini E and Fallahi P: CXCR3, CXCL10 and type 1 diabetes. Cytokine Growth Factor Rev 25: 57-65, 2014.

19. Antonelli A, Ferrari SM, Giuggioli D, Ferrannini E, Ferri C and Fallahi P: Chemokine (C-X-C motif) ligand (CXCL)10 in autoimmune diseases. Autoimmun Rev 13: 272-280, 2014.

20. Fallahi P, Ferrari SM, Ruffilli I, Elia G, Biricotti M, Vita R, Benvenga $S$ and Antonelli A: The association of other autoimmune diseases in patients with autoimmune thyroiditis: Review of the literature and report of a large series of patients. Autoimmun Rev 15: 1125-1128, 2016.

21. Antonelli A, Fallahi P, Delle Sedie A, Ferrari SM, Maccheroni M, Bombardieri S, Riente L and Ferrannini E: High values of Th1 (CXCL10) and Th2 (CCL2) chemokines in patients with psoriatic arthtritis. Clin Exp Rheumatol 27: 22-27, 2009.

22. Ingram JL, Antao-Menezes A, Turpin EA, Wallace DG, Mangum JB, Pluta LJ, Thomas RS and Bonner JC: Genomic analysis of human lung fibroblasts exposed to vanadium pentoxide to identify candidate genes for occupational bronchitis. Respir Res 8: 34, 2007.

23. Antao-Menezes A, Turpin EA, Bost PC, Ryman-Rasmussen JP and Bonner JC: STAT-1 signaling in human lung fibroblasts is induced by vanadium pentoxide through an IFN-beta autocrine loop. J Immunol 180: 4200-4207, 2008.

24. Sabbioni E, Kuèera J, Pietra R and Vesterberg O: A critical review on normal concentrations of vanadium in human blood, serum, and urine. Sci Total Environ 188: 49-58, 1996.

25. Assem FL and Levy LS: A review of current toxicological concerns on vanadium pentoxide and other vanadium compounds: Gaps in knowledge and directions for future research. J Toxicol Environ Health B Crit Rev 12: 289-306, 2009. 